\title{
ASSOCIATION NEWS
}

NEW ENROLMENT

\begin{tabular}{|c|c|c|c|}
\hline SL. NO. & NAME & GRADE & DATE OF ELECTION \\
\hline 1. & Er. Avishek Ganguly & (LM) & $22 / 9 / 2012$ \\
\hline 2. & Er. Sourav Bhattacharya & (LM) & , \\
\hline 3. & Er. Pranab Ray & $(\mathrm{LF})$ & , \\
\hline 4. & TMC Institute of Learning & (L Inst. M) & " \\
\hline 5. & Dr. Pranab Kumar Dan & (LF) & $10 / 11 / 2012$ \\
\hline 6. & Er. Sujit Majumdar & (LF) & " \\
\hline 7. & Dr. Raju Shrihari Pawade & $(\mathrm{LF})$ & 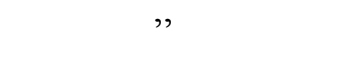 \\
\hline 8. & Er. Debashis Sarkar & $(\mathrm{LF})$ & , \\
\hline 9. & Er. Pradip Kumar Mukherjee & (LF) & " \\
\hline 10. & Dr. Parthasarathi Bera & (LF) & , \\
\hline 11. & Er. Uttam Roy & (LF) & , \\
\hline 12. & Er. Mohammed Ismail & (LF) & , \\
\hline 13. & Er. Sirsendu Mahata & (LF) & " \\
\hline 14. & Er. Pranab Kumar Kundu & (LM) & , \\
\hline 15. & Er. Anirban Sarkar & (LM) & $”$ \\
\hline 16. & Er. Krishnendu Mondal & (LM) & " \\
\hline 17. & Er. Parimal Chandra Majumder & $(\mathrm{LM})$ & , \\
\hline 19. & Prof. Dr. Asish Bandyopadhyay & $\begin{array}{c}(\mathrm{LF}) \\
\text { Converted from (M) }\end{array}$ & " \\
\hline
\end{tabular}




\section{REPORT}

The 37th International MATADOR Conference was organized by Prof. Srichand Hinduja and Prof. Lin Li as the Organising Secretary at the University of Manchester, Manchester, United Kingdom on July 25-27, 2012. The name, MATADOR stands for Manufacturing (M), Automation and systems (A), Technology (T), Applications (A), Design (D), Organisation and management $(\mathrm{O})$ and Research $(\mathrm{R})$, and the theme of this conference was focused on these areas. The International Academy of Production Engineering (CIRP) instituted a CIRP Best Paper Award to be given to the best paper presented in the MATADOR Conference which is one of the oldest conferences in manufacturing field. More than 100 papers were presented by the authors from 31 countries in 3 parallel technical sessions. Sessions on Cutting/Machining, Machine Tool, Welding, Casting, Forming, Manufacturing Systems and Automation, Computer Aided Engineering and Design for Manufacture, Metrology, Laser Processing, ECM, EDM, Surface Modification, Rapid Prototyping, Additive Manufacturing and Micro/Nano Fabrication were organised.

The paper with the title, "Development of an Abbé Error Compensation for NC Machine Tools" presented by Prof. K.C. Fan of National Taiwan University, Taiwan was adjudged to be the recipient of the CIRP Best Paper Award. A total of 13 papers were there from India. Prof. Santanu Das of the Department of Mechanical Engineering, Kalyani Govt. Engineering College, Kalyani presented a paper on "The Effect of In-Plane Exit Angle on Burr Minimization in Face Milling of Medium Carbon Steels in Dry Environment" on July 25, 2012 in the Technical Session I on Cutting/Machining. There were 6 Keynote paper presentations and 12 Invited Lectures delivered by eminent researchers in their respective fields. Poster presentations were also arranged.

The first Keynote paper was on "Sustainable Manufacturing from a Global Perspective" by Prof. F. Van Houten, Past President of the CIRP and of the University of Twente, Netherlands, where as the 2nd one was on "Nuclear Manufacturing - the Needs and Challenge" by Prof. Michael Burke of The University of Manchester, UK and the 3rd one was presented by Prof. Minlin Zhong of Tsinghua University, China on "Laser Additive Manufacturing in China- from Fundamental Research to Industrial Applications". Fourth Keynote address was entitled "Advances in Electro-discharge and Electro-chemical Micromachining" delivered by Prof. Masanori Kunieda of The University of Tokyo, Japan. Prof. Shui-Li Gong of the National Key Laboratory of Power Beam Processes, China presented the 5th Keynote Lecture on "Advanced Welding Technologies and Applications" while Prof. Xiang-Qian Jiang of the University of Huddersfield, UK delivered the 6th one on "Paradigm Shifts in Surface Metrology".

Visit to different state-of-the-art laboratories, specially, Nuclear Engineering laboratory consisting of High precision Machining and Welding equipment, and Nano- Science and Technology laboratory, of the University of Manchester, arranged on July 27, 2012, was worth noting. With the closing remarks, the curtain of the 37th MATADOR Conference, 2012 was down on July 27, 2012.

Santanu Das

-Acting Editor, Journal of the Association of Engineers, India

Report. 


\section{REPORT}

4th International and 25th All International Manufacturing Technology, Design and Research (AIMTDR) Conference, 2012 was held at Jadavpur University, Kolkata on December 14-16, 2012. This biennial conference is a quite old conference in the area of manufacturing started way back in 1967 at Jadavpur University only. In its Silver Jubilee year, the Department of Production Engineering of Jadavpur University got the responsibility to organize the same with Prof. Bijoy Bhattacharyya as the Organising Secretary.

In the inaugural ceremony, the Chief Guest, Mr. S.K. Beri, DGOF \& Chairman, Ordnance Factory Board, Kolkata outlined the need of the day in manufacturing sector in the parlance of production of defence equipment. He stressed on the need of collaborative work between the industry and academics to develop the state-of-the-art technology to manufacture majority of precision items in India itself. Guests of Honour, Prof. S. Bhattacharyya, the Vice-Chancellor of Jadavpur University, Prof. V.K. Jain of IIT, Kanpur and Prof. S. Datta, the Pro Vice-Chancellor of Jadavpur University addressed the audience on this occasion.

Prof. Amitabha Bhattacharyya Memorial Lecture was delivered by Prof. S.K. Basu of Govt. College of Engineering, Pune on "The Challenges of Condition Based Risk and Reliability Centered Maintenance in Engineering Design and Manufacture", and Dr. S.M. Patil Memorial Lecture was delivered by Mr. S.G. Shirgurkar of ACE Designers Ltd., Bengaluru on "Ace Designers Limited: A Case Study". Commemoration address of the 25th AIMTDR Conference was given by Prof. V. Radhakrishnan of Indian Institute of Space Science and Technology, Trivandrum. Apart from these lectures, six Key Note Lectures were presented by Prof. K.P. Rajurkar of University of Nebraska, USA, Prof. S. Chandrasekhar of Purdue University, USA, Prof. M. Rahaman of National University of Singapore, Prof. T.P. Bagchi of NMIMS, Shirpur and Dr. V.K. Suri of BARC, Mumbai. There were five parallel technical sessions, and about 287 technical papers were presented in the conference.

Prof. Santanu Das, Acting Editor of the Journal of the Association of Engineers, India chaired a Technical Session IV(C) on December 15, 2012. Prof. Das was also a member of the Organising Committee and Technical Committee of 4th International and 25th AIMTDR Conference.

At the end of the three-day conference, six best paper awards were announced. One of the three papers coauthored by Prof. Das got a best paper award. The paper bears the title, "Effect of Using Different Methods of Fluid Application on Grinding Performance" authored by Sirsendu Mahata, Jayanta Mistri, Bijoy Mandal and Santanu Das. All authors of this award winning paper are members of the Association of Engineers, India.

With a happy note, this largest conference in the area of manufacturing in India ended with an announcement to hold the 5th International and 26th All International Manufacturing Technology, Design and Research (AIMTDR) Conference, 2014 at IIT, Guwahati.

Santanu Das

- Acting Editor, Journal of the Association of Engineers, India 


\section{COURSES OFFERED}

\section{By The Association of Engineers, India}

\begin{tabular}{|c|c|c|c|}
\hline Sr. no & Course details & Duration & $\begin{array}{c}\text { Session } \\
\text { Starts }\end{array}$ \\
\hline $\mathbf{1 .}$ & $\begin{array}{c}\text { Post Diploma Programme } \\
\text { (a) Part time Diploma in } \\
\text { Industrial Safety }\end{array}$ & 18 months & $\begin{array}{c}\text { Contact } \\
\text { AEI }\end{array}$ \\
\hline $\mathbf{2 .}$ & $\begin{array}{l}\text { Short Term Vocational } \\
\text { Training Programme } \\
\text { (a) Construction Supervisor } \\
\text { 'O' Level } \\
\text { (b) Construction Supervisor } \\
\text { 'A' Level }\end{array}$ & Six Months & Six Months \\
\hline \multicolumn{2}{|c|}{ Approved and recognized by the West Bengal State } \\
Council of Technical Education who conducts \\
examinations and award certificates.
\end{tabular}

\section{One-Day Technical Programme on \\ Rain Water Harvesting (RWH) \\ May be Organised \\ on}

\section{Request}

(This is in addition to our 2 day Technical Programme being offered to turn out competent RWH personnel.) 